\title{
Treatment with Gefitinib, an Epidermal Growth Factor Receptor Inhibitor, Decreases Serum Cholesterol in Patients with Lung Cancer
}

\author{
Yea Eun Kang, Ji Min Kim, Kyong Hye Joung, Hyun Jin Kim, Bon Jeong Ku* \\ Department of Internal Medicine, Chungnam National University School of Medicine, Daejeon, Korea
}

Background: Statins are used to treat hypercholesterolemia; however, major cardiovascular events are decreased only $30 \%$ by statin treatment. Treatment with an epidermal growth factor receptor (EGFR) tyrosine kinase inhibitor has been reported to decrease serum glucose levels and improved insulin sensitivity in mice and humans, but there was no study in serum cholesterol levels. This study examined the effect of gefitinib, an EGFR tyrosine kinase inhibitor, on cholesterol metabolism in humans.

Methods: We retrospectively reviewed the medical records of 299 patients with primary lung cancer treated with gefitinib for $\geq 1$ month and 72 patients with other treatments. Serum cholesterol, serum triglycerides, and body mass index were measured before and after treatment. The changes in serum cholesterol, serum triglycerides, and body mass index were compared between the gefitinib treatment group and the control group and were also analyzed according to the presence or absence of EGFR mutations.

Results: Serum cholesterol levels decreased significantly from 178.9 to $164.4 \mathrm{mg} / \mathrm{dL}$ after 1 -month of gefitinib treatment. A total of 54 of the 299 patients underwent examination for the presence of the EGFR mutations. Serum cholesterol was significantly decreased in the group with the activating EGFR mutation $(\Delta=21.3 \mathrm{mg} / \mathrm{dL})$ compared to that of those without the EGFR mutation $(\Delta=-3.1 \mathrm{mg} / \mathrm{dL})$ after treatment with gefitinib. In contrast, there was no significantly difference between the two groups in control patients.

Conclusion: Treatment with gefitinib decreased serum cholesterol in lung cancer patients, particularly in those with activating mutations in EGFR. These data suggest that EGFR tyrosine kinase inhibitors provide a novel and attractive strategy for the treatment of hypercholesterolemia.

Key words: Gefitinib, Cholesterol, Lung neoplasm

\section{Introduction}

Hypercholesterolemia is a major modifiable risk factor for cardiovascular disease. ${ }^{1}$ According to current guidelines for the management of hypercholesterolemia, statins are the recommended gold standard treatment for the prevention of cardiovascular disease. Statins are 3-hydroxy-3-methylglutaryl coenzyme A reductase inhibitors. ${ }^{2}$ However, large clinical trials revealed that statins decreased major cardiovascular events by $30 \%{ }^{3}$ In addition, some patients did not achieve their target cholesterol levels using statin therapy alone ${ }^{4}$, and some patients also experienced side effects such as myalgia, muscle aches, constipation, and serious rhabdomyolysis. ${ }^{2,4}$ Because these patients required dose reduction or the discontinuation of statin treatment ${ }^{5}$, another treatment modality is needed to replace statins.
Epidermal growth factor receptor (EGFR) is an epidermal growth factor receptor tyrosine kinase family member and major regulator of cellular homeostasis. ${ }^{6}$ Previously, we demonstrated that the serum cholesterol and hepatic lipid contents were increased in mice overexpressing EGFR via the liver-specific knockout of mitogen-inducible gene 6 (Mig-6), a negative feedback inhibitor of EGFR. ${ }^{7}$ We detected decreased serum cholesterol levels and improved fatty liver in these mice after treatment with gefitinib, an EGFR tyrosine kinase inhibitor (TKI). Prada et al. ${ }^{8}$ reported that treatment with an EGFR TKI improved glucose tolerance and insulin action in mice fed a high-fat diet. Recently, the effects of several TKIs on glucose metabolism and insulin sensitivity were reported in humans. ${ }^{9-12}$ In the current study, we hypothesized that EGFR plays a role in cholesterol metabolism and that EGFR TKIs could be novel drugs for the treatment of hy-
*Corresponding author Bon Jeong Ku (iD http://orcid.org/0000-0002-3414-8949 Department of Internal Medicine, Chungnam National University School of Medicine, 282 Munhwa-ro, Jung-gu, Daejeon 35015, Korea

Tel: +82-42-280-7148 Fax: +82-42-280-7995 E-mail: bonjeong@cnu.ac.kr

Received Jul. 31, 2015 Reviewed Sep. 18, 2015 Accepted Dec. 16, 2015
Copyright ( $(2016$ Korean Society for the Study of Obesity

() This is an Open Access article distributed under the terms of the Creative Commons Attribution Non-Commercial License (http://creativecommons.org/licenses/by-nc/4.0/) which permits unrestricted non-commercial use, distribution, and reproduction in any medium, provided the original work is properly cited. 
percholesterolemia. To our knowledge, no studies have assessed the effects of EGFR TKIs on serum cholesterol levels in humans. Therefore, we investigated the effects of EGFR TKI gefitinib on serum cholesterol levels in non-small cell lung cancer patients.

\section{Methods}

\section{Study participants}

Patients with histologically confirmed primary lung cancer between January 2001 and December 2012 were enrolled in this study. All data were collected retrospectively by a comprehensive review of the patients' medical charts. We divided the patients into two groups (gefitinib treatment and control groups) according to the treatment they received. A total of 299 patients who underwent gefitinib treatment for at least 1 month were included in the gefitinib treatment group. Patients who took gefitinib for less than 1 month, who received mixed therapy consisting of gefitinib and other anticancer drugs, or who were prescribed medications known to influence serum lipid levels (e.g., angiotensin II receptor blockers or statins) were excluded from the study. A total of 72 patients who underwent other forms of treatment (e.g., operative treatment, chemotherapy, or radiotherapy) were included in the control group to evaluate changes in lipid profiles following alternate cancer therapy. Informed consent was obtained from all patients after the nature of the procedure had been fully explained. This study was approved by the Institutional Review Board of Chungnam National University Hospital (Daejeon, Korea).

\section{Clinical and laboratory profiles}

Information on patient age, sex, body mass index $\left(\mathrm{kg} / \mathrm{m}^{2}\right)$, cancer stage at diagnosis, pathology reports, and laboratory profiles were collected through medical chart reviews. Blood chemistry and lipid profiles were measured using a blood chemistry analyzer (Hitachi 747; Tokyo, Japan). Gefitinib was administered orally at a dose of 250 $\mathrm{mg} /$ day. We analyzed laboratory and clinical parameters before and 1 month after gefitinib treatment to investigate the efficacy of gefitinib. EGFR genotyping was performed using a PNAClamp ${ }^{\mathrm{TM}}$ EGFR Mutation Detection kit (Panagene, Inc., Daejeon, Korea).

\section{Statistical analyses}

Statistical analyses were performed using SPSS version 18.0 statistical software (SPSS Inc., Chicago, IL, USA). Differences in the base- line characteristics of the two groups were analyzed using independent sample $t$-tests or a one-way analysis of variance. A paired $t$-test was used to compare the means of the measured variables. The association between EGFR mutations and the variables evaluated was assessed using analysis of covariance and linear regression analysis with Bonferroni corrections. Results are expressed as means \pm SEM. In all analyses, $P<0.05$ was used to indicate statistical significance.

\section{Results}

\section{Patient characteristics}

The characteristics of the 371 enrolled participants who were diagnosed with primary lung cancer are presented in Table 1 . In the gefitinib treatment group, $62.2 \%$ of the patients were male, and $37.8 \%$ were female. The mean $( \pm$ SEM) age of the patients at diagnosis was 65.3 (9.9) years, and the mean ( \pm SEM) body mass index was $23.0(3.0) \mathrm{kg} / \mathrm{m}^{2}$. Overall, $65 \%$ of the patients were diagnosed with stage IV disease, while $11.7 \%$ were diagnosed with stage III disease. Adenocarcinoma was the most common tumor type (64.5\%), followed by squamous cell carcinoma (30.1\%). In total, $42.8 \%$ of the participants had a history of smoking. In the control group, most of the baseline characteristics, including patient age, sex, cancer stage, and histologic findings, were not significantly different from those in the gefitinib treatment group, but body mass index was lower $(P=0.028)$ and number of patients with presence of EGFR mutation was lower $(P=0.016)$ than gefitinib treatment group.

Among the 54 patients who had adequate tissue samples available for molecular analyses in the gefitinib treatment group, 26 had EGFR mutations while 28 had none. In the control group, among the 25 patients who had adequate tissue samples available for molecular analyses, 9 had EGFR mutations, while 16 had none. The patients were divided into two groups according to the presence of EGFR mutations (those with and those without). The baseline characteristics of the 54 patients for whom molecular analyses were conducted are presented in Table 2 . There were no statistically significant differences in any baseline parameters between the two groups.

\section{Effects of gefitinib treatment on clinical and laboratory parameters}

We investigated changes in several parameters in 299 patients before and 1 month after treatment with gefitinib. There were no statis- 
Table 1. Baseline characteristics of the clinical and laboratory information of patients with lung cancer included in this study

\begin{tabular}{|c|c|c|c|}
\hline Characteristics & $\begin{array}{l}\text { Control Group } \\
\qquad(\mathrm{N}=72)\end{array}$ & $\begin{array}{c}\text { Gefitinib treatment } \\
\text { group }(N=299)\end{array}$ & $P$ value \\
\hline Age (year) & $65.7 \pm 9.5$ & $65.3 \pm 9.9$ & $0.082^{*}$ \\
\hline \multicolumn{4}{|l|}{ Sex } \\
\hline Male & $48(66.7)$ & $186(62.2)$ & $0.086^{\dagger}$ \\
\hline Female & 24 (33.3) & $113(37.8)$ & \\
\hline Height (cm) & $162.2 \pm 7.3$ & $160.4 \pm 7.8$ & $0.053^{*}$ \\
\hline Weight (kg) & $58.0 \pm 9.9$ & $59.2 \pm 9.3$ & $0.392^{*}$ \\
\hline Body mass index $\left(\mathrm{kg} / \mathrm{m}^{2}\right)$ & $22.0 \pm 3.5$ & $23.0 \pm 3.0$ & $0.028^{*}$ \\
\hline \multicolumn{4}{|l|}{ Cancer stage } \\
\hline I & $9(12.5)$ & $18(6)$ & $0.063^{\dagger}$ \\
\hline$\|$ & $4(5.6)$ & $52(17.4)$ & \\
\hline III & $25(34.7)$ & $35(11.7)$ & \\
\hline IV & $34(47.2)$ & $194(64.9)$ & \\
\hline \multicolumn{4}{|l|}{ Smoking status } \\
\hline Non smoker & $164(54.8)$ & $164(54.8)$ & $0.229^{\dagger}$ \\
\hline Former or Current smoker & $128(42.8)$ & $128(42.8)$ & \\
\hline Unknown & $7(2.3)$ & $7(2.3)$ & \\
\hline \multicolumn{4}{|l|}{ Histology } \\
\hline Adenocarcinoma & $39(54.2)$ & $193(64.5)$ & $0.071^{\dagger}$ \\
\hline Squamous cell carcinoma & $26(36.1)$ & $90(30.1)$ & \\
\hline NSCLC & $4(5.6)$ & $14(4.7)$ & \\
\hline Neuroendocrine carcinoma & $3(4.2)$ & $2(0.7)$ & \\
\hline \multicolumn{4}{|l|}{ EGFR mutation } \\
\hline EGFR mutation + & $9(12.5)$ & $26(8.7)$ & $0.016^{\dagger}$ \\
\hline EGFR mutation - & $16(22.2)$ & $28(9.4)$ & \\
\hline No evaluation & $47(65.3)$ & $245(81.9)$ & \\
\hline \multicolumn{4}{|l|}{ Clinical chemistry } \\
\hline Sodium (mEq/L) & $139.6 \pm 5.3$ & $138.1 \pm 2.9$ & $0.780^{*}$ \\
\hline Potassium (mEq/L) & $4.0 \pm 0.5$ & $4.2 \pm 0.4$ & $0.927^{*}$ \\
\hline Creatinine (mg/dL) & $0.90 \pm 0.3$ & $0.83 \pm 0.2$ & $0.132^{*}$ \\
\hline Protein (g/dL) & $6.8 \pm 0.7$ & $6.9 \pm 0.7$ & $0.883^{*}$ \\
\hline Hemoglobin (g/dL) & $12.2 \pm 1.8$ & $11.9 \pm 1.7$ & $0.601^{*}$ \\
\hline Leukocytes (× 103/ML) & $6.849 \pm 2.518$ & $6.919 \pm 3.613$ & $0.455^{*}$ \\
\hline \multicolumn{4}{|l|}{ Lipid level } \\
\hline Total cholesterol (mg/dL) & $178.6 \pm 40.8$ & $178.9 \pm 40.5$ & $0.655^{*}$ \\
\hline Triglyceride (mg/dL) & $134.6 \pm 72.5$ & $134.4 \pm 73.1$ & $0.886^{*}$ \\
\hline
\end{tabular}

Data are expressed as mean \pm SD or number (\%).

*Derived from an independent $t$-test between control group and gefitinib treatment; ${ }^{\dagger}$ Derived from a Mann-Whitney $U$ test between control group and gefitinib treatment. NSCLC, non-small cell lung cancer; EGFR, epidermal growth factor receptor.

tically significant changes in weight or body mass index in the gefitinib treatment group (Table 3). Further, in the gefitinib treatment group, the total cholesterol level decreased from 178.9 to $164.4 \mathrm{mg} / \mathrm{dL}$ $(P=0.000)$, and the triglyceride level decreased from 134.4 to 126.7 $\mathrm{mg} / \mathrm{dL}(P=0.056)$ (Fig. 1A). No significant differences were detected in the control group.

To evaluate the general nutritional status of the patients, protein and leukocyte levels were compared; no statistically significant dif-
Table 2. Baseline characteristics of the clinical and pathological information of lung cancer patients according to EGFR mutation in gefitinib treatment group $(\mathrm{N}=54)$

\begin{tabular}{lccc}
\hline Characteristics & $\begin{array}{c}\text { With EGFR } \\
\text { mutation (N=26) }\end{array}$ & $\begin{array}{c}\text { Without EGFR } \\
\text { mutation (N=28) }\end{array}$ & $P$ value \\
\hline Age (year) & $67.4 \pm 13.4$ & $65.1 \pm 11.8$ & $0.504^{*}$ \\
Sex & & & \\
$\quad$ Male & $7(26.9)$ & $14(50)$ & \\
$\quad$ Female & $19(73.1)$ & $14(50)$ & $0.085^{\dagger}$ \\
Height (cm) & $156.6 \pm 8.6$ & $159.0 \pm 7.1$ & $0.276^{*}$ \\
Weight (kg) & $55.3 \pm 10.7$ & $59.6 \pm 9.0$ & $0.121^{*}$ \\
Body mass index (kg/m²) & $22.5 \pm 3.4$ & $23.6 \pm 3.5$ & $0.241^{*}$ \\
Cancer stage & & & \\
I & $1(3.8)$ & $1(3.6)$ & \\
॥I & $2(7.7)$ & $6(21.4)$ & \\
III & $2(7.7)$ & $1(3.6)$ & \\
$\quad$ IV & $21(80.8)$ & $20(71.4)$ & $0.316^{\dagger}$ \\
Smoking status & & & \\
$\quad$ Non smoker & $21(80.8)$ & $20(71.4)$ & \\
Former or current smoker & $5(19.2)$ & $8(28.6)$ & $0.430^{\dagger}$ \\
Histology & & & \\
Adenocarcinoma & $26(100)$ & $24(85.7)$ & $0.061^{\dagger}$ \\
Squamous cell carcinoma & & $3(10.7)$ & \\
NSCLC & & $1(3.6)$ & \\
\hline
\end{tabular}

Data are expressed as mean \pm SD or number (\%).

*Derived from an independent $t$-test between group with EGFR mutation and group without EGFR mutation; 'Derived from a Mann-Whitney $U$ test between group with EGFR mutation and group without EGFR mutation.

NSCLC, non-small cell lung cancer.

Table 3. Changes of various parameters in gefitinib treatment group ( $N=299$ )

\begin{tabular}{lccc}
\hline Parameters & $\begin{array}{c}\text { Before gefitinib } \\
\text { treatment }\end{array}$ & $\begin{array}{c}\text { After gefitinib } \\
\text { treatment }\end{array}$ & $P$ value \\
\hline Weight $(\mathrm{kg})$ & $60.4 \pm 9.5$ & $59.9 \pm 10.1$ & $0.075^{*}$ \\
Body mass index $\left(\mathrm{kg} / \mathrm{m}^{2}\right)$ & $23.3 \pm 3.3$ & $23.1 \pm 3.6$ & $0.104^{*}$ \\
Sodium $(\mathrm{mEq} / \mathrm{L})$ & $138.1 \pm 2.9$ & $138.3 \pm 3.0$ & $0.428^{*}$ \\
Potassium $(\mathrm{mEq} / \mathrm{L})$ & $4.2 \pm 0.4$ & $4.1 \pm 0.4$ & $0.012^{* \dagger}$ \\
Hemoglobin $(\mathrm{g} / \mathrm{dL})$ & $11.9 \pm 1.7$ & $12.1 \pm 1.6$ & $0.004^{* \dagger}$ \\
Leukocytes $\left(\times 10^{3} / \mathrm{\mu L}\right)$ & $6.919 \pm 3.613$ & $7.137 \pm 2.684$ & $0.286^{*}$ \\
Total cholesterol $(\mathrm{mg} / \mathrm{dL})$ & $178.9 \pm 40.5$ & $164.4 \pm 38.2$ & $0.000^{* \dagger}$ \\
Triglyceride $(\mathrm{mg} / \mathrm{dL})$ & $134.4 \pm 73.1$ & $126.7 \pm 63.1$ & $0.056^{*}$ \\
Protein $(\mathrm{g} / \mathrm{dL})$ & $6.9 \pm 0.7$ & $6.8 \pm 0.6$ & $0.761^{*}$ \\
Creatinine $(\mathrm{mg} / \mathrm{dL})$ & $0.83 \pm 0.2$ & $0.87 \pm 0.2$ & $0.045^{* \dagger}$ \\
\hline
\end{tabular}

Data are expressed as mean \pm SD.

${ }^{*}$ Derived from a paired $t$-test between before gefitinib treatment and after gefitinib treatment; ${ }^{\dagger} P<0.05$ between before gefitinib treatment and after gefitinib treatment.

ferences were observed. Creatinine levels increased $(P=0.012)$, while potassium levels decreased $(P=0.045)$; however, the changes remained within the normal range and were not clinically significant (Table 3). Among the 72 patients who underwent some other treatment for primary lung cancer, there were no significant differences in 

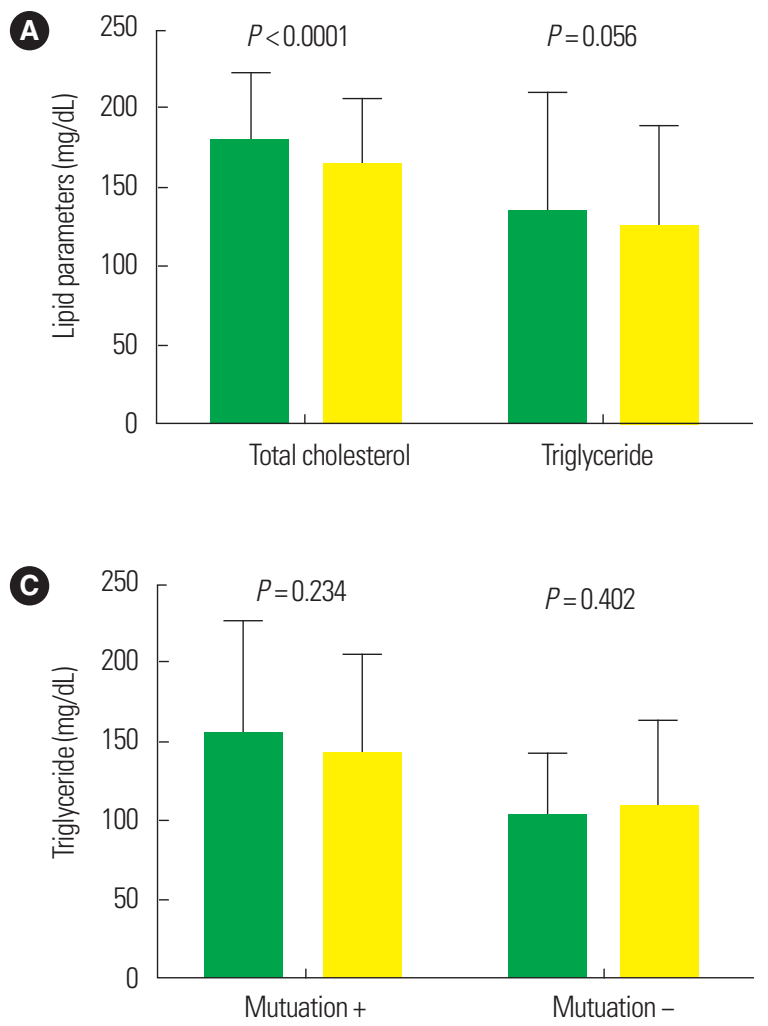

Table 4. Changes of various parameters in control group ( $N=72)$

\begin{tabular}{lccc}
\hline Parameters & Before treatment & After treatment & $P$ value \\
\hline Weight $(\mathrm{kg})$ & $58.0 \pm 9.9$ & $58.3 \pm 10.1$ & $0.130^{*}$ \\
Body mass index $\left(\mathrm{kg} / \mathrm{m}^{2}\right)$ & $22.0 \pm 3.5$ & $22.1 \pm 3.2$ & $0.103^{*}$ \\
Sodium $(\mathrm{mEg} / \mathrm{L})$ & $139.6 \pm 5.3$ & $139.6 \pm 6.2$ & $0.156^{*}$ \\
Potassium $(\mathrm{mEg} / \mathrm{L})$ & $4.0 \pm 0.5$ & $4.0 \pm 0.4$ & $0.525^{*}$ \\
Hemoglobin $(\mathrm{g} / \mathrm{dL})$ & $12.2 \pm 1.8$ & $12.2 \pm 1.8$ & $0.171^{*}$ \\
Leukocytes $\left(\times 10^{3} / \mathrm{ML}\right)$ & $6.849 \pm 2.518$ & $6.850 \pm 2.519$ & $0.394^{*}$ \\
Total cholesterol $(\mathrm{mg} / \mathrm{dL})$ & $178.6 \pm 40.8$ & $177.2 \pm 42.7$ & $0.873^{*}$ \\
Triglyceride $(\mathrm{mg} / \mathrm{dL})$ & $134.6 \pm 72.5$ & $125.5 \pm 74.1$ & $0.302^{*}$ \\
Protein $(\mathrm{g} / \mathrm{dL})$ & $6.8 \pm 0.7$ & $6.8 \pm 0.6$ & $0.625^{*}$ \\
Creatinine $(\mathrm{mg} / \mathrm{dL})$ & $0.90 \pm 0.3$ & $0.87 \pm 0.2$ & $0.207^{*}$ \\
\hline
\end{tabular}

Data are expressed as mean \pm SD.

${ }^{*}$ Derived from a paired $t$-test between before treatment and after treatment.

any of the parameters evaluated, including the lipid profile (Table 4).

\section{Effects of gefitinib treatment on various parameters}

\section{according to EGFR mutation status}

We compared patients with and without EGFR mutations to evaluate the effect of EGFR mutations on serum lipid levels; however, there were no significant differences in body weight or serum levels of hemoglobin, protein, sodium, or potassium between the two groups (Table 5).

Interestingly, patients with activating EGFR mutations exhibited a

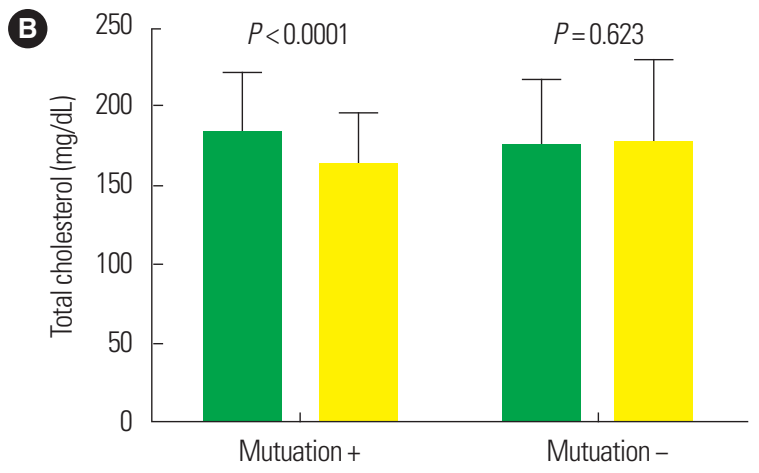

Figure 1. Changes of serum lipid profiles in patients with lung cancer after gefitinib treatment. (A) Changes in serum lipid levels in lung cancer patients after gefitinib treatment. Serum total cholesterol level significantly decreased in gefitinib treatment group compared with in control group $(P<0.0001)$, but there was no significant difference of triglyceride level between gefitinib treatment group and control group $(P=0.056)$. (B) Changes in total cholesterol levels after gefitinib treatment according to EGFR mutation status. Serum total cholesterol level significantly decreased in gefitinib treatment group with EGFR mutation status $(P<0.0001)$, but there was no significant difference between gefitinib treatment group without EGFR mutation status $(P=0.623)$. (C) Changes in triglyceride levels after gefitinib treatment according to EGFR mutation status. There was no significant difference of triglyceride levels between gefitinib treatment group according to EGFR mutation status. Green bar; lipid profile before gefitinib treatment, Yellow bar; lipid profile after gefitinib treatment.

Table 5. Association with changes of various parameters in gefitinib treatment group according to EGFR mutation

\begin{tabular}{lccc}
\hline Parameters & $\begin{array}{c}\text { With EGFR } \\
\text { mutation }(\mathrm{N}=26)\end{array}$ & $\begin{array}{c}\text { Without EGFR } \\
\text { mutation }(\mathrm{N}=28)\end{array}$ & $P$ value \\
\hline$\Delta$ Weight $(\mathrm{kg})$ & $-0.39 \pm 1.0$ & $-0.15 \pm 1.9$ & $0.705^{*}$ \\
$\Delta$ Body mass index $\left(\mathrm{kg} / \mathrm{m}^{2}\right)$ & $-0.15 \pm 0.4$ & $-0.01 \pm 0.7$ & $0.539^{*}$ \\
$\Delta$ Sodium $(\mathrm{mEq} / \mathrm{L})$ & $-0.4 \pm 2.8$ & $0.7 \pm 2.4$ & $0.119^{*}$ \\
$\Delta$ Potassium $(\mathrm{mEq} / \mathrm{L})$ & $-0.06 \pm 0.8$ & $0.73 \pm 2.4$ & $0.157^{*}$ \\
$\Delta$ Hemoglobin $(\mathrm{g} / \mathrm{dL})$ & $-0.07 \pm 1.5$ & $-0.23 \pm 1.5$ & $0.711^{*}$ \\
$\Delta$ Leukocytes $\left(\times 10^{3} / \mu \mathrm{L}\right)$ & $0.038 \pm 3.045$ & $-0.911 \pm 2.279$ & $0.204^{*}$ \\
$\Delta$ Total cholesterol $(\mathrm{mg} / \mathrm{dL})$ & $21.3 \pm 22.6$ & $-3.1 \pm 33.1$ & $0.003^{* \dagger}$ \\
$\Delta$ Triglyceride $(\mathrm{mg} / \mathrm{dL})$ & $10.8 \pm 40.2$ & $-8.0 \pm 46.7$ & $0.151^{*}$ \\
\hline
\end{tabular}

Data are expressed as mean $\pm S D$.

$\Delta$ indicates the change of value (value after gefitinib treatment - value before gefitinib treatment).

${ }^{*}$ Derived from an independent $t$-test analysis between group with EGFR mutation and group without EGFR mutation; ${ }^{\dagger} P<0.05$ between group with EGFR mutation and group without EGFR mutation.

$21.3 \mathrm{mg} / \mathrm{dL}$ decrease in total cholesterol from the baseline value after 1 month of treatment with gefitinib. Patients with EGFR mutations showed a decrease in total cholesterol from $178 \pm 43$ to $152 \pm 37(P<$ $0.001)$, but there was no significant difference in patients without EGFR mutations ( $P=0.623$; Fig. 1B). Additionally, we analyzed changes in triglyceride levels in relation to EGFR mutation, but there was no significant change between the groups (Fig. 1C). Also, we an- 
Table 6. Association with changes of various parameters in control group according to EGFR mutation

\begin{tabular}{lccc}
\hline Parameters & $\begin{array}{c}\text { With EGFR } \\
\text { mutation }(\mathrm{N}=9)\end{array}$ & $\begin{array}{c}\text { Without EGFR } \\
\text { mutation }(\mathrm{N}=16)\end{array}$ & $P$ value \\
\hline$\Delta$ Weight $(\mathrm{kg})$ & $-0.19 \pm 1.1$ & $-0.15 \pm 1.7$ & $0.402^{*}$ \\
$\Delta$ Body mass index $\left(\mathrm{kg} / \mathrm{m}^{2}\right)$ & $-0.04 \pm 0.4$ & $-0.03 \pm 0.7$ & $0.209^{*}$ \\
$\Delta$ Sodium $(\mathrm{mEq} / \mathrm{L})$ & $-1.4 \pm 4.8$ & $-0.3 \pm 3.8$ & $0.504^{*}$ \\
$\Delta$ Potassium $(\mathrm{mEq} / \mathrm{L})$ & $-0.09 \pm 0.6$ & $0.11 \pm 0.3$ & $0.288^{*}$ \\
$\Delta$ Hemoglobin $(\mathrm{g} / \mathrm{dL})$ & $-0.25 \pm 1.1$ & $-0.43 \pm 1.2$ & $0.727^{*}$ \\
$\Delta$ Leukocytes $\left(\times 10^{3} / \mathrm{LL}\right)$ & $0.505 \pm 1.53$ & $-0.430 \pm 1.55$ & $0.158^{*}$ \\
$\Delta$ Total cholesterol $(\mathrm{mg} / \mathrm{dL})$ & $-6.4 \pm 32$ & $6.1 \pm 44$ & $0.464^{*}$ \\
$\Delta$ Triglyceride $(\mathrm{mg} / \mathrm{dL})$ & $-7.9 \pm 18.0$ & $5.6 \pm 61.4$ & $0.529^{*}$ \\
\hline
\end{tabular}

Data are expressed as mean \pm SD.

$\Delta$ indicates the change of value (value after gefitinib treatment - value before gefitinib treatment).

*Derived from an independent $t$-test analysis between group with EGFR mutation and group without EGFR mutation.

alyzed the changes in cholesterol and triglyceride levels in relation to the EGFR mutation in the gefitinib treatment and control groups. In the gefitinib treatment group, the change of cholesterol was significant in patients with the EGFR mutation $(P=0.003$; Table 5), but there was no differences in the control group (Table 6).

\section{Discussion}

In this study, we investigated the potential role of EGFR TKI gefitinib in the treatment of hypercholesterolemia. We found that serum cholesterol levels decreased by $8.1 \%$ from baseline levels after treatment with gefitinib for 1 month in patients with non-small cell lung cancer. Moreover, the cholesterol-lowering effects were more significant in lung cancer patients who had activating EGFR mutations.

EGFR TKIs were initially reported as a treatment option for cancer. ${ }^{13-15}$ Recently, several studies have reported that the drug also affects nutrient metabolism. When patients with a malignancy and type 2 diabetes were treated with TKIs, both conditions improved. ${ }^{16}$ However, no previous studies have assessed the cholesterol-lowering effects of TKIs. To the best of our knowledge, this is the first report demonstrating statistically significant changes in serum cholesterol levels following gefitinib treatment.

There are several mechanisms by which gefitinib could decrease serum cholesterol levels. First, EGFR TKIs exert anti-inflammatory effects. In high-fat diet fed mice, EGFR TKI treatment improved insulin resistance by decreasing proinflammatory components. ${ }^{8}$ For example, erlotinib inhibits TNF- $\alpha$ secretion by suppressing activated
T cells. ${ }^{17}$ Second, gefitinib might alter bile acid synthesis. In mice in which EGFR was activated by deletion of the Mig- 6 gene, we reported that hypercholesterolemia occurred via the downregulation of major enzymes related to bile acid synthesis. ${ }^{7}$ We also observed that serum cholesterol levels were decreased by gefitinib treatment in these mice. ${ }^{18}$ Interestingly, in our current study, serum cholesterol levels were decreased more in patients with EGFR activating mutations than in those without EGFR mutations. These data support the aforementioned results obtained in gefitinib-treated Mig- 6 knockout mice. ${ }^{7}$ However, additional studies are needed to validate and evaluate the exact mechanism underlying these effects.

Statins, cholesterol absorption inhibitors, nicotinic acid, and bile acid sequestrants are currently used to lower serum cholesterol. ${ }^{2}$ These drugs have been used for several decades, but their preventive effects on cardiovascular-related events are disappointing. ${ }^{3}$ Statins decrease serum cholesterol levels from 17 to $31 \%$ of baseline levels. ${ }^{19}$ In the current study, serum cholesterol was decreased by $8.1 \%$ of baseline levels in non-small cell lung cancer patients treated with gefitinib. In patients with EGFR activating mutations, serum cholesterol levels were decreased by $11.5 \%$ of baseline levels. The potency of the cholesterol-lowering effect was lower after treatment with gefitinib compared with statins. Nevertheless, statin therapy has some limitations in terms of a limited preventive effect on cardiovascular events, the attainment of target cholesterol levels, and adverse effects. ${ }^{3,5}$ We hypothesize that gefitinib could be used as an additive or alternative therapy in these cases. In particular, these combined or alternative treatments could be more effective in patients with activating EGFR mutations. When we consider that serum cholesterol levels were decreased more in patients with EGFR activating mutations, measuring EGFR signaling might facilitate individualized treatment planning in statin-resistant patients.

There are limitations to our current study. First, all of our subjects were cancer patients. The effects of gefitinib might be affected by the presence versus absence of cancer in patients. Second, lifestyle factors that influence serum cholesterol levels, particularly cholesterol intake and serum levels of each cholesterol fraction, were not monitored in this retrospective study. Third, the effect of tumor progression on cholesterol level could not be excluded. Fourth, since this study was retrospective, there were differences in several clinical characteristics between participants such as lung cancer tumor stage and BMI. Lastly, serum level of LDL-C and HDL-C, the important 
parameter of metabolic syndrome, were not investigated in this study. To overcome these limitations, a large-scale, prospective, randomized controlled clinical trial is needed.

In conclusion, we found that serum cholesterol levels were decreased by gefitinib treatment in patients with non-small cell lung cancer, particularly in patients with EGFR activating mutations. EGFR TKI gefitinib might be useful as both a classical anticancer drug as well as an alternative or additive therapy for the treatment of hypercholesterolemia.

\section{Conflicts of Interest}

The authors declare no conflict of interest.

\section{Acknowledgments}

This work was supported by a National Research Foundation of Korea (NRF) grant funded by the Korean Government (NRF-2013 R1A1A2004719).

\section{References}

1. Kronmal RA, Cain KC, Ye Z, Omenn GS. Total serum cholesterol levels and mortality risk as a function of age. A report based on the Framingham data. Arch Intern Med 1993;153:1065-73.

2. Stone NJ, Robinson JG, Lichtenstein AH, Bairey Merz CN, Blum $\mathrm{CB}$, Eckel RH, et al. American College of Cardiology/American Heart Association Task Force on Practice Guidelines. 2013 ACC/ AHA guideline on the treatment of blood cholesterol to reduce atherosclerotic cardiovascular risk in adults: a report of the American College of Cardiology/American Heart Association Task Force on Practice Guidelines. J Am Coll Cardiol 2014;63(25 Pt B):2889-934.

3. Sacks FM, Pfeffer MA, Moye LA, Rouleau JL, Rutherford JD, Cole TG, et al. The effect of pravastatin on coronary events after myocardial infarction in patients with average cholesterol levels. Cholesterol and Recurrent Events Trial investigators. N Engl J Med 1996;335:1001-9.

4. National Cholesterol Education Program (NCEP) Expert Panel on detection, Evaluation, and Treatment of High blood cholesterol in Adults (Adult Treatment Panel III). Third report of the National
Cholesterol Education Program (NCEP) expert panel on detection, evaluation, and treatment of high blood cholesterol in adults (Adult Treatment Panel III) final report. Circulation 2002;106: 3143-421.

5. Pasternak RC, Smith SC Jr, Bairey-Merz CN, Grundy SM, Cleeman JI, Lenfant C, et al. ACC/AHA/NHLBI clinical advisory on the use and safety of statins. J Am Coll Cardiol 2002;40:567-72.

6. Segatto $\mathrm{O}$, Anastasi $\mathrm{S}$, Alemà $\mathrm{S}$. Regulation of epidermal growth factor receptor signalling by inducible feedback inhibitors. J Cell Sci 2011;124:1785-93.

7. Ku BJ, Kim TH, Lee JH, Buras ED, White LD, Stevens RD, et al. Mig-6 plays a critical role in the regulation of cholesterol homeostasis and bile acid synthesis. PLoS One 2012;7:e42915.

8. Prada PO, Ropelle ER, Mourão RH, de Souza CT, Pauli JR, Cintra DE, et al. EGFR Tyrosine Kinase Inhibitor (PD153035) improves glucose tolerance and insulin action in highfat diet-fed mice. Diabetes 2009;58:2910-9.

9. Mokhtari D, Welsh N. Potential utility of small tyrosine kinase inhibitors in the treatment of diabetes. Clin Sci (Lond) 2009;118: 241-7.

10. Fitter S, Vandyke K, Schultz CG, White D, Hughes TP, Zannettino AC. Plasma adiponectin levels are markedly elevated in imatinibtreated chronic myeloid leukemia (CML) patients: a mechanism for improved insulin sensitivity in type 2 diabetic CML patients? J Clin Endocrinol Metab 2010;95:3763-7.

11. Tsapas A, Vlachaki E, Sarigianni M, Klonizakis F, Paletas K. Restoration of insulin sensitivity following treatment with imatinib mesylate (Gleevec) in non-diabetic patients with chronic myelogenic leukemia (CML). Leuk Res 2008;32:674-5.

12. Gottardi M, Manzato E, Gherlinzoni F. Imatinib and hyperlipidemia. N Engl J Med 2005;353:2722-3.

13. Scaltriti M, Baselga J. The epidermal growth factor receptor pathway: a model for targeted therapy. Clin Cancer Res 2006;12:526872.

14. Fry DW, Kraker AJ, McMichael A, Ambroso LA, Nelson JM, Leopold WR, et al. A specific inhibitor of the epidermal growth factor receptor tyrosine kinase. Science 1994;265:1093-5.

15. Rae JM, Lippman ME. Evaluation of novel epidermal growth factor receptor tyrosine kinase inhibitors. Breast Cancer Res Treat 2004;83:99-107.

16. Costa DB, Huberman MS. Improvement of type 2 diabetes in a 
lung cancer patient treated with Erlotinib. Diabetes Care 2006; 29:1711.

17. Luo Q, Gu Y, Zheng W, Wu X, Gong F, Gu L, et al. Erlotinib inhibits T-cell-mediated immune response via down-regulation of the c-Raf/ERK cascade and Akt signaling pathway. Toxicol Appl Pharmacol 2011;251:130-6.

18. Lee JC, Park BK, Choung S, Kim JM, Joung KH, Lee JH, et al.
Amelioration of hypercholesterolemia by an EGFR tyrosine kinase inhibitor in mice with liver-specific knockout of Mig-6. PLoS One 2014;9:e114782.

19. Edwards JE, Moore RA. Statins in hypercholesterolaemia: a dosespecific meta-analysis of lipid changes in randomised, double blind trials. BMC Fam Pract 2003;4:18. 